\title{
THE MECHANISM AND INTERRELATIONSHIPS OF THE FLOCCULATION TESTS
}

\author{
BY \\ N. F. MACLAGAN, N. H. MARTIN, AND J. BARBARA LUNNON \\ From the Departments of Chemical Pathology at Westminster Medical School and at \\ St. George's Hospital Medical School, London
}

(RECEIVED FOR PUBLICATION OCTOBER 23, 1951)

So many flocculation tests have been developed during the last few years that the time appears ripe to attempt a critical review of the mechanism and usefulness of some of the more popular procedures. Although many of these tests were developed primarily in relation to liver disease, where they are of proved value, it is generally recognized that they are not all specific in this respect. There is no doubt, however, that they can throw useful light on the qualitative and quantitative changes in the pattern of the circulating proteins in disease. Earlier work in this field was recently reviewed by one of us (Maclagan, 1948) and the present paper deals with more recent contributions.

\section{Mechanism of the Tests}

The mechanism of the tests can best be discussed in relation to the factors known to affect protein solubility. These will be discussed under the following headings : $H$ ion concentration $(p H)$ and salt concentration and ionic pattern (of the environment) ; protein concentration ; modification of polar or non-polar protein groups.

Table I compares six commonly used flocculation tests with regard to these factors.

It will be recalled that Hardy in 1905 pointed out that the globulins in particular tended to be insoluble near the acid side of their iso-electric point. If we accept Kekwick's (1940) figure of 6.58 as the iso-electric point of $\gamma$-globulin it will be seen that Popper's flocculation test using ammonium sulphate is particularly adjusted to precipitate $\gamma$-globulin. In view of the high salt concentration employed $(2.0 \mathrm{M})$ this test may probably be regarded as a modification of the ordinary salting out procedures.

In contrast to this the molarity of the zinc sulphate test is pitched so low (0.001 M) that, although, as Kunkel (1947) has shown so conclusively, its readings are closely correlated with changes in $\gamma$-globulin, it can hardly depend upon salting out effects. It seemed probable that in this test an insoluble metal complex is formed, and to test this hypothesis we have carried out the following experiment.

In the first tube a $1 \%$ solution of $95 \%$ pure $\gamma$-globulin prepared by ether fractionation was added to equal volumes of 0.001 molar $\mathrm{ZnSO}_{4}$ solution and distilled water; at the same time in a second tube a $1 \%$ solution of the same $\gamma$-globulin was added to equal volumes of the same $\mathrm{ZnSO}_{4}$ solution to which had been added an equal volume of a 
TABLE I

COMParison of Six Flocculation Tests

\begin{tabular}{|c|c|c|c|c|c|}
\hline & \multirow{2}{*}{$p \mathbf{H}$} & \multicolumn{2}{|c|}{ Ionic Pattern } & \multirow{2}{*}{$\begin{array}{l}\text { Approxi- } \\
\text { mate } \\
\text { Molarity }\end{array}$} & \multirow{2}{*}{$\begin{array}{l}\text { Protein Con- } \\
\text { centration } \\
\text { (g./100 ml.) }\end{array}$} \\
\hline & & Cations & Ions & & \\
\hline $\begin{array}{l}\text { Ammonium sulphate test } \\
\text { (de la Huerga and Popper, } \\
\text { 1950) } \quad .\end{array}$ & $5 \cdot 3$ & $\underset{\mathrm{Na}}{\mathrm{NH}_{4}}$ & $\mathrm{SO}_{4}$ & $2 \cdot 0$ & $0 \cdot 14$ \\
\hline $\begin{array}{c}\text { Takata-Ara test } \\
\text { (Jezler, 1930) }\end{array}$ & $12 \cdot 0$ & $\begin{array}{l}\mathrm{Hg} \\
\mathrm{Na}\end{array}$ & $\begin{array}{c}\mathrm{Cl} \\
\left(\mathrm{CO}_{3}\right)\end{array}$ & $0 \cdot 1$ & $3 \cdot 0-0 \cdot 3$ \\
\hline $\begin{array}{crr}\text { Cadmium sulphate } & \text { test } \\
\text { (Wuhrmann and } & \text { Wun- } \\
\text { derly, 1947) } & \ldots & . .\end{array}$ & $7 \cdot 0$ & $\mathrm{Cd}$ & $\mathrm{SO}_{4}$ & $0 \cdot 1$ & $4 \cdot 6$ \\
\hline $\begin{array}{l}\text { Thymol test } \\
\text { (Maclagan, 1944b) }\end{array}$ & $7 \cdot 8$ & $\begin{array}{c}\text { Thymol } \\
\mathrm{Na}\end{array}$ & Barbitone & 0.01 & $0 \cdot 14$ \\
\hline $\begin{array}{l}\text { Zinc sulphate test } \\
\text { (Kunkel, 1947) }\end{array}$ & $7 \cdot 5$ & $\begin{array}{l}\mathrm{Zn} \\
\mathrm{Na}\end{array}$ & $\begin{array}{c}\mathrm{SO}_{4} \\
\text { Barbitone }\end{array}$ & 0.001 & $0 \cdot 14$ \\
\hline $\begin{array}{l}\text { Colloidal gold test } \\
\text { (Maclagan, 1944a) }\end{array}$ & $7 \cdot 8$ & $\begin{array}{c}\mathrm{Au} \\
\mathrm{Na} \\
\text { Phenol }\end{array}$ & $\begin{array}{l}\text { Barbitone } \\
\text { Cl } \\
\text { Citrate }\end{array}$ & 0.01 & $0 \cdot 14$ \\
\hline
\end{tabular}

saturated solution of pure glycine in distilled water. As a control to the two systems a third tube of the original $1 \% \gamma$-globulin solution was diluted with two volumes of distilled water. The three systems were examined periodically over 48 hours at $20^{\circ} \mathrm{C}$.

Flocculation occurred in the first tube within five minutes followed by precipitation in two hours, and at the end of two hours the third, control, tube was slightly opalescent, the second tube containing the glycine remaining clear and unchanged over the whole period of the observation. The glycine has a stability constant with $\mathrm{Zn}$ of 9.2 as measured in the laboratory where this test was carried out (Perkins, 1952) which compares closely with the published figure of 9.3 of Albert (1950). $\mathrm{Zn}$ has a higher coordinating capacity than either ferric or ferrous iron, iron being the only metal likely to be present in the system capable of forming co-ordinating complexes.

Our interpretation of this simple experiment is that at the concentration described the glycine forms a soluble co-ordination complex with the $\mathrm{Zn}$ ions available which are not therefore available to co-ordinate with the $\gamma$-globulin, the stability constant of which is probably much lower than glycine.

While the only unassailable evidence would be the isolation and characterization of the zinc globulin complex we do believe that this experiment is extremely suggestive, especially when taken in conjunction with Lewin's (1951) work on the crystallization of the metallic salts of albumin.

The colloidal gold test presumably depends upon a similar mechanism as it operates at a similar $p \mathrm{H}$ and ionic strength $(0.01 \mathrm{M})$. It will be shown later that the gold and zinc sulphate tests are strongly correlated with each other.

The mechanism of the thymol test appears to be more complex. Unlike the other tests considered there is little correlation with total serum globulin (see below). Maclagan and Bunn (1947) demonstrated that in this test turbidity only occurs in the presence of phospholipid. This would normally be contributed by the $\beta$-globulin fraction, but the addition of cephalin was an effective substitute. (This may explain the observations of Cohen and Thompson (1947) that the $\beta$-globulin which is rich 
in phospholipid is partially carried down in the thymol precipitate.) In the presence of cephalin $\gamma$-globulin was the only fraction that produced turbidity.

Maclagan and Bunn also showed that albumin inhibited the reaction and that hepatitis albumin was a less effective inhibitor than normal albumin. Martin (1948, 1949), studying the inhibitory effect of crystalline human and bovine albumin on the thymol reaction, confirmed these findings and stressed particularly the differences between normal and hepatitis albumin. These qualitative changes in the albumin fraction are evidently of the greatest significance in this test. Martin also described an unusual type of $\gamma$ globulin showing spontaneous precipitation during electrophoresis and giving positive flocculation tests when added to normal serum.

TABLE II

Effect of Intravenous Albumin Administration on Five Patients with Positive Flocculation Tests

\begin{tabular}{|c|c|c|c|c|c|c|c|}
\hline \multicolumn{3}{|c|}{ Albumin (g. intravenously) } & 50 & 58 & 60 & 75 & 100 \\
\hline $\begin{array}{l}\text { Thymol test } \\
\text { Zinc sulphate test } \\
\left(\mathrm{NH}_{4}\right)_{2} \mathrm{SO}_{4} \text { test } \\
\text { Colloidal gold test }\end{array}$ & $\begin{array}{l}\ldots \\
\cdots \\
\cdots \\
\ldots\end{array}$ & $\begin{array}{l}\cdots \\
\cdots \\
\cdots\end{array}$ & $\begin{array}{l}55 \%^{*} \\
20 \% \\
15 \% \\
12 \%\end{array}$ & $\begin{array}{l}60 \% \\
33 \% \\
30 \% \\
20 \%\end{array}$ & $\begin{array}{l}50 \% \\
25 \% \\
20 \% \\
-\end{array}$ & $\begin{array}{l}50 \% \\
= \\
-\end{array}$ & $\begin{array}{l}65 \% \\
25 \% \\
15 \% \\
-\end{array}$ \\
\hline
\end{tabular}

$* \%$ reduction of flocculation in units.

It remained to study the effect of albumin administered in vivo. Table II shows the results of five such experiments and indicates the important part that normal albumin plays in preventing abnormal thymol flocculation, for in every instance the intravenous administration of albumin produced a fall in the intensity of the thymol reaction. The other flocculation tests were similarly affected but to a smaller extent. Even more striking is a serial study carried out on a patient with extensive liver necrosis who received a single transfusion of serum albumin (Fig. 1).

The base line in Fig. 1, 100\%, represents the levels estimated at three-day intervals over seven days before the intravenous administration of $60 \mathrm{~g}$. of albumin dissolved in $300 \mathrm{ml}$. of 0.15 molar saline. Subsequent levels were estimated at the completion of the transfusion, 18 hours after and 48 hours after, and thereafter at the intervals shown on the chart. Fig. 1 shows that, 20 days after transfusion, the flocculation tests were all within the limits of the base line, and that in the interval between the levels were reduced to a varying extent; the ammonium sulphate test least, the zinc sulphate test next, and the thymol test to the greatest extent for the greatest period of time. It is noteworthy that the depression of the thymol test corresponded roughly to the expected time of survival of a significant amount of the infused albumin.

The complexity of factors involved in the thymol test will be recognized from the above discussion, but it is evident that qualitative and quantitative changes in the albumin and $\gamma$-globulin fractions are the most important items.

Less work appears to have been done on the mechanism of the cadmium sulphate and Takata-Ara tests. These both employ an intermediate ionic strength $(0.1 \mathrm{M})$ together with metallic cations and perhaps depend upon a combination of salting out with the formation of insoluble metal complexes. The very high $p \mathrm{H}$ of the 


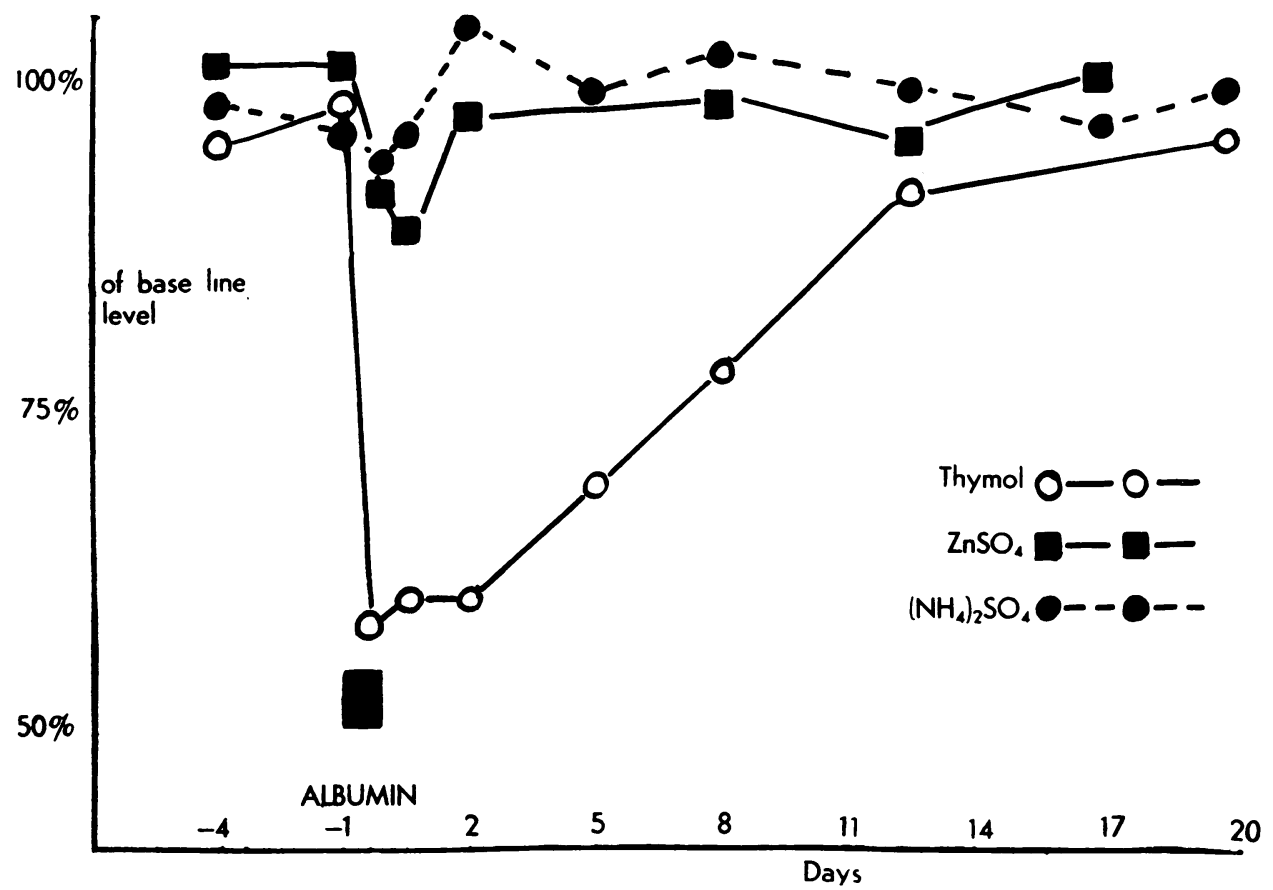

Fig. 1.-Effect of intravenous albumin administration $(60 \mathrm{~g}$.) on flocculation tests in a case of hepatitis.

Takata-Ara test is noteworthy (about 12.0) and must produce some degree of denaturation of the proteins concerned.

\section{Correlation Between Tests}

It is well recognized that there is a strong family resemblance between the various tests and a pronounced tendency to correlation between them, while at the same time considerable discrepancies may occur in individual cases. To obtain further information on this point we have examined the correlation coefficients between the five tests in which we have been mainly interested, taken in pairs. The correlation

TABLE III

Cases Used for Calculation of Correlation Coefficients

\begin{tabular}{|c|c|c|c|c|c|}
\hline \multirow{2}{*}{ Test } & & \multicolumn{4}{|c|}{ Diagnosis } \\
\hline & & Hepatitis & $\begin{array}{c}\text { Obstructive } \\
\text { Jaundice }\end{array}$ & Miscellaneous* & Totals \\
\hline $\begin{array}{ll}\text { Thymol } & \ldots \\
\text { Gold }^{2} & \ldots \\
\mathrm{ZnSO}_{4} & \ldots\end{array}$ & $\begin{array}{l}\cdots \\
\cdots \\
\cdots \\
\cdots\end{array}$ & $\begin{array}{l}93 \\
93 \\
93 \\
53 \\
23\end{array}$ & $\begin{array}{r}30 \\
30 \\
30 \\
13 \\
5\end{array}$ & $\begin{array}{r}117 \\
117 \\
117 \\
52 \\
55\end{array}$ & $\begin{array}{r}240 \\
240 \\
240 \\
118 \\
83\end{array}$ \\
\hline
\end{tabular}

* "Miscellaneous" includes all cases other than hepatitis and obstructive jaundice, omitting those with all tests normal. 
of each test with total serum globulin and with the albumin/globulin ratio was also examined.

The material used in this study is shown in Table III and includes all cases seen under the relevant headings with certain exceptions. Thus 298 miscellaneous cases (i.e. cases other than hepatitis or obstructive jaundice) in which every test was negative are excluded, and in addition 52 cases in which the diagnosis was uncertain and 14 cases of multiple myelomatosis were excluded. The last was necessary since it had previously been shown that there was a special tendency to dissociation between the tests in this condition (Earle, Martin, and Maclagan, 1951). This point will be further discussed in the next section.

The following list gives the methods used :

\begin{tabular}{|c|c|c|c|c|}
\hline Test & & & Reference & Normal Limits \\
\hline $\begin{array}{l}\text { Thymol turbidity test } \\
\text { Thymol flocculation test } \\
\text { Serum colloidal gold reaction } \\
\text { Zinc sulphate turbidity test } \\
\text { Ammonium sulphate turbidity }\end{array}$ & $\begin{array}{l}\cdots \\
\cdots \\
\cdots \\
\text { test }\end{array}$ & $\begin{array}{l}\cdots \\
\cdots \\
\cdots \\
\cdots \\
\cdots\end{array}$ & $\begin{array}{l}\text { Maclagan (1944b) } \\
\text { Maclagan (1947) } \\
\text { Maclagan (1944a) } \\
\text { Kunkel (1947) } \\
\text { de la Huerga and Popper (1950) }\end{array}$ & $\begin{array}{l}0-2 \text { units } \\
0-1+ \\
0 \\
0-4 \text { units } \\
0-2 \quad,\end{array}$ \\
\hline
\end{tabular}

The turbidity units for all tests are based on diluted normal serum treated with salicylsulphonic acid as described by Maclagan (1947). They are therefore not identical with the units proposed by the authors of the zinc sulphate and ammonium sulphate turbidity tests. The normal limits were those obtained with a group of 30 normal subjects.

The serum protein estimations were made by the micro-Kjeldahl method, using a Markham (1942) all-glass distillation apparatus. The globulin was precipitated with

TABLE IV

Corkelation Coefficients ( \pm Standard Errors) between flocculation Tests and Serum Proteins in Non-Myeloma Cases

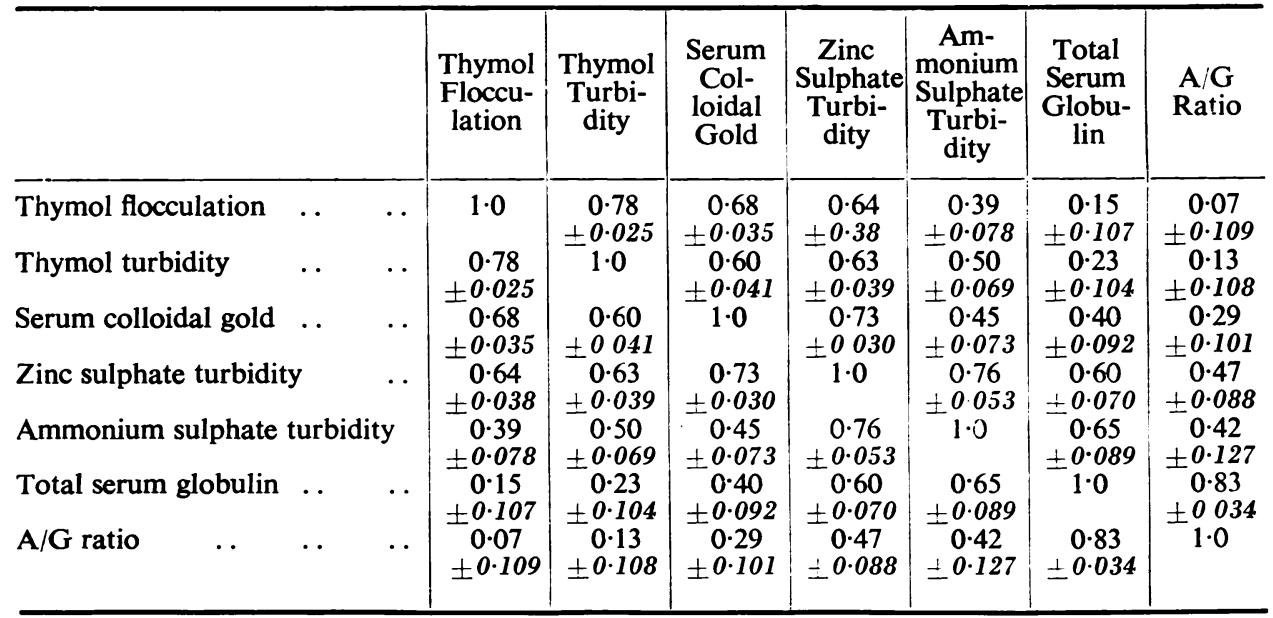

The signs of the correlation coefficients are omitted from the table. They were all positive except for the $\mathbf{A} / \mathbf{G}$ ratio figures, which were negative. 
$22 \% \mathrm{w} / \mathrm{v} \mathrm{Na} \mathrm{Na}_{2}$. The proteins were digested for two hours after clearing, using a selenate catalyst.

The results of this work are shown in Table IV, two typical correlation diagrams being illustrated in Figs. 2 and 3. Owing to the fact that different numbers of cases have been employed in some correlations as compared with others, the standard errors will be seen to vary somewhat, but as a rough guide it may be taken that any pair of correlation coefficients differing by more than 0.1 are probably statistically different. For example, 0.64 (zinc sulphate turbidity and thymol flocculation) in the table is significantly different from 0.78 (thymol turbidity and thymol flocculation) but does not differ significantly from 0.68 (gold and thymol flocculation).

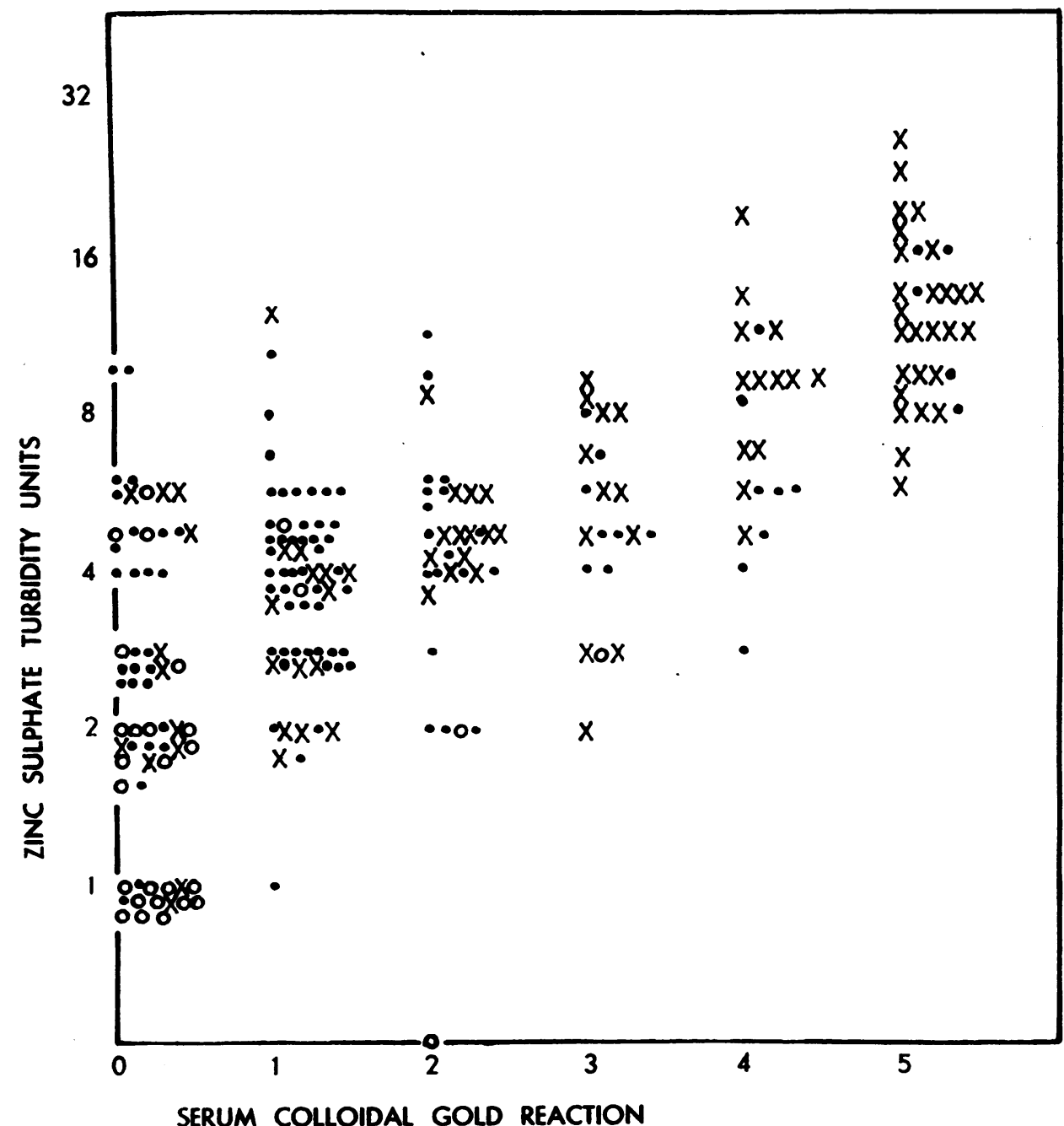

Fig. 2.-Correlation between $\mathrm{ZnSO}_{4}$ turbidity and serum colloidal gold reaction in 240 cases. $\mathrm{X}=$ hepatitis $; \mathrm{O}=$ obstructive jaundice; $\boldsymbol{\theta}=$ miscellaneous. Correlation coefficient $0 \cdot 73 \pm 0 \cdot 030$. 


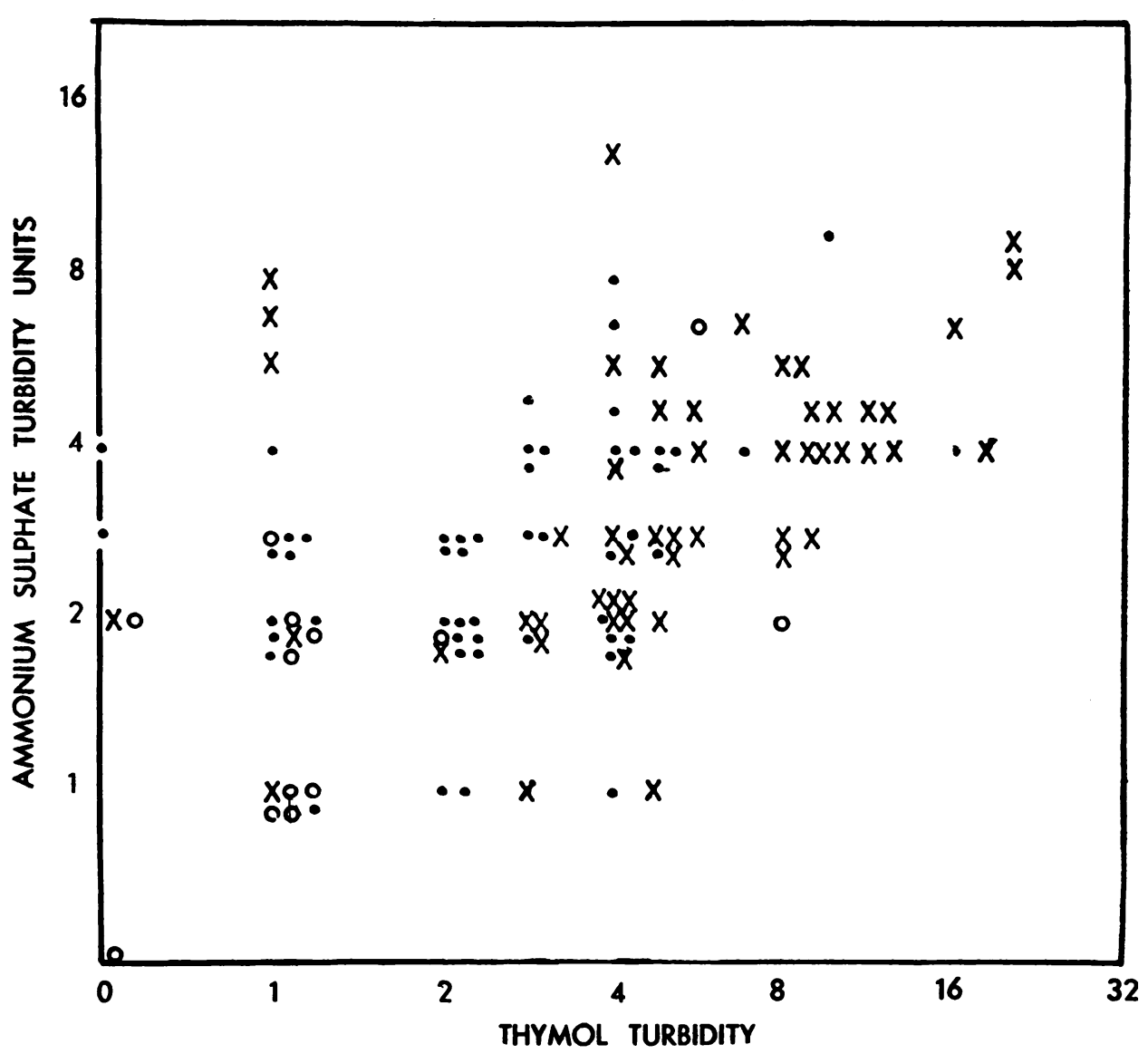

FIG. 3.-Correlation between $\left(\mathrm{NH}_{4}\right)_{2} \mathrm{SO}_{4}$ turbidity and thymol turbidity in 118 cases. ' $\mathrm{X}=$ hepatitis; $\mathrm{O}=$ obstructive jaundice $; \boldsymbol{\theta}=$ miscellaneous. Correlation coefficient $0.50 \pm 0.069$.

It will be seen from Table IV that it has been possible to arrange the tests in the following order : albumin/globulin ratio, total serum globulin, ammonium sulphate turbidity, zinc sulphate turbidity, serum colloidal gold reaction, thymol turbidity and flocculation, which expresses the tendency of the tests to correlate with one another. Thus the tests appearing close together in this list are more strongly correlated than those which are more widely separated. This is illustrated by the gradation of correlation coefficients as one proceeds across or down the table.

It is also evident that there is a tendency for the tests to be arranged in three groups : (1) thymol turbidity and flocculation; (2) gold and zinc sulphate ; and (3) ammonium sulphate and total serum globulin. The correlation within each group is much closer than that between the groups, and group 2 occupies an intermediate position between groups 1 and 3 as shown by the higher correlation between groups 1 and 2 and between groups 2 and 3 as opposed to the lower correlation between groups 1 and 3. The albumin/globulin ratio occupies a position rather outside these three groups as it shows a weak correlation with a few of the tests only. The lower 
correlation between the thymol tests and the albumin/globulin ratio as compared with the serum globulin is somewhat surprising. Although it is not statistically significant for each individual test, this general trend appears to be quite clear. The explanation may probably lie in the variation in the extent of the qualitative changes in the albumin from one serum to another. These qualitative changes are not of necessity mirrored in the albumin/globulin ratio.

It is interesting that the order of tests obtained by this study of correlation is almost identical with the order indicating the probability of obtaining positive results in myelomatosis (see below). The relationships outlined here are not unexpected in view of the different mechanisms of the tests referred to above. Thus, the ammonium sulphate test and the total globulin estimation are operating in high salt concentration, the gold and zinc sulphate tests probably depend upon some specific interaction with metallic cations at low ionic strength, whereas the thymol test evidently depends upon some entirely different mechanism.

\section{Myelomatosis}

Whereas in a case of hepatitis most of the different flocculation tests are usually either positive or negative, in a case of myelomatosis it is frequently found that some tests are strongly positive while others are completely negative (Earle, Martin, and Maclagan, 1951).

We have collected some further evidence on this point and the results of the various tests in our total series of cases of plasmacytoma are shown in Table V. It will be seen that this confirms our previous finding of the marked tendency to dissociation between the tests in this disease, a dissociation which exceeds that seen in any other condition. It was also found that the tests could be arranged in a definite order corresponding to the probability of obtaining positive results. This is the order shown in the table and is total serum globulin, albumin/globulin ratio,

TABLE V

Flocculation Tests and Serum Proteins in 14 Cases of Plasmacytoma

\begin{tabular}{|c|c|c|c|c|c|c|c|}
\hline $\begin{array}{l}\text { Case } \\
\text { No. }\end{array}$ & $\begin{array}{l}\text { Total } \\
\text { Serum } \\
\text { Globulin } \\
(\mathrm{g} . \%)\end{array}$ & $\begin{array}{c}\text { A/G } \\
\text { Ratio }\end{array}$ & $\underset{\text { Turbidity }}{\left(\mathrm{NH}_{\mathbf{4}}\right)_{2} \mathrm{SO}_{4}}$ & $\begin{array}{c}\mathrm{ZnSO}_{4} \\
\text { Turbidity }\end{array}$ & $\begin{array}{l}\text { Serum } \\
\text { Colloidal } \\
\text { Gold Test }\end{array}$ & $\begin{array}{l}\text { Thymol } \\
\text { Turbidity }\end{array}$ & $\begin{array}{l}\text { Thymol } \\
\text { Floc- } \\
\text { culation }\end{array}$ \\
\hline $\begin{array}{r}1 \\
2 \\
3 \\
4 \\
5 \\
6 \\
7 \\
8 \\
9 \\
10 \\
11 \\
12 \\
13 \\
14\end{array}$ & $\begin{array}{r}3 \cdot 1 \\
1.4 \\
8.5 \\
6.4 \\
5.8 \\
7.0 \\
6.0 \\
10.2 \\
9.4 \\
8.0 \\
8.3 \\
10.1 \\
5.7 \\
6.7\end{array}$ & $\begin{array}{l}1.61 * \\
3.50 \\
0.86 \\
0.42 \\
0.57 \\
0.34 \\
0.55 \\
0.24 \\
0.21 \\
0.05 \\
0.22 \\
0.24 \\
0.72 \\
0.43\end{array}$ & $\begin{array}{c}2 \\
+++ \\
4 \\
2 \\
7 \\
32 \\
21 \\
21 \\
21 \\
18\end{array}$ & $\begin{array}{r}3 \\
1 \\
5 \\
0 \\
0 \\
0 \\
0 \\
2 \\
18 \\
80 \\
0 \\
0 \\
28 \\
28\end{array}$ & $\begin{array}{l}0 \\
0 \\
1+ \\
0 \\
0 \\
0 \\
0 \\
0 \\
0 \\
5+ \\
0 \\
0 \\
0 \\
5+\end{array}$ & $\begin{array}{r}1 \\
1 \\
1 \\
0 \\
0 \\
0 \\
0 \\
1 \\
1 \\
12 \\
2 \\
1 \\
1 \\
0\end{array}$ & $\begin{array}{l}0 \\
0 \\
0 \\
0 \\
0 \\
0 \\
0 \\
0 \\
0 \\
4+ \\
0 \\
0 \\
0 \\
0 \\
0\end{array}$ \\
\hline
\end{tabular}

- Normal results in italics.

+ Immediate heavy flocculation, turbidity could not be measured. 
ammonium sulphate turbidity, zinc sulphate turbidity, serum colloidal gold reaction, thymol turbidity, and flocculation. The tests at the beginning of this list are more likely to be positive than those at the end, and in our small series we have so far encountered no case of myeloma showing the converse of this. If, for example, the zinc sulphate test is negative the gold and thymol are negative, whereas if the thymol test is positive all the other tests are positive. It is interesting that this order of tests is the same as that given by the study of correlation coefficients in non-myeloma cases reported above, with the exception of the total globulin and albumin/globulin ratio which are in the reverse order in the two lists.

The most frequent finding in myelomatosis appears to be a high globulin with low albumin/globulin ratio and strongly positive ammonium sulphate and zinc sulphate, the remaining tests being negative. It will be seen from Table IV that a degree of dissociation sufficiently striking for diagnostic purposes was found in 12 out of 14 cases, the two exceptions being Case 2 (all results normal) and Case 10 (all results abnormal). In our opinion this type of dissociation is a valuable diagnostic pointer in myelomatosis as we have not seen it in any other disease.

\section{Summary}

The fundamental factors contributing to a number of flocculation tests have been reviewed and the degree of correlation of one test with another has been examined. Evidence is produced to show that on this basis the flocculation tests which we have studied may be grouped into three main families. The tests within each group are closely correlated, but the correlation between groups is less close.

(1) Tests, such as the ammonium sulphate, which may be regarded primarily as modifications of the classical salting out procedures; (2) the colloidal gold and zinc sulphate tests in which the formation of a metallic complex is the probable fundamental mechanism ; (3) tests, such as the thymol test, in which complex formation of a more complicated nature is concerned, probably involving a protein-protein linkage.

The advantage of using a battery of tests is stressed, particularly in the case of myelomatosis in which there is a special and perhaps unique tendency to dissociation between the tests.

\section{REFERENCES}

Albert, A. (1950). Biochem. J., 47, 531.

Cohen, P. C., and Thompson, F. (1947). J. Lab. clin. Med., 32, 314.

Earle, J. H. O., Martin, N. H., and Maclagan, N. F. (1951). Proc. Ass. clin. Path., Journal of Clinical Pathology, 4, 117.

Huerga, J. de la, and Popper, H. (1950). J. Lab. clin. Med., 35, 459.

Hardy, W. B. (1905). J. Physiol., Lond., 33, 251.

Jezler, A. (1930). Z. klin. Med., 114, 739.

Kekwick, R. A. (1940). Biochem. J., 34, 1248.

Kunkel, H. G. (1947). Proc. Soc. exp. Biol., N.Y., 66, 217.

Lewin, J. (1951). J. Amer. chem. Soc., 73, 3906.

Maclagan, N. F. (1944a). Brit. J. exp. Path., 25, 15. (1944b). Ibid., 25, 234.

(1947). Brit. med.J., $2,197$.

(1948). Ibid., 2, 892.

and Bunn, D. (1947). Biochem. J., 41, 580.

Markham, R. (1942). Ibid., 36, 790.

Martin, N. H. (1948). Nature, Lond., $162,145$.

(1949). Journal of Clinical Pathology, 2, 275.

Perkins, D. J. (1952). In the press.

Wuhrmann, F., and Wunderly, C. (1947). Die Bluteiweisskörper des Menschen. Basel. 